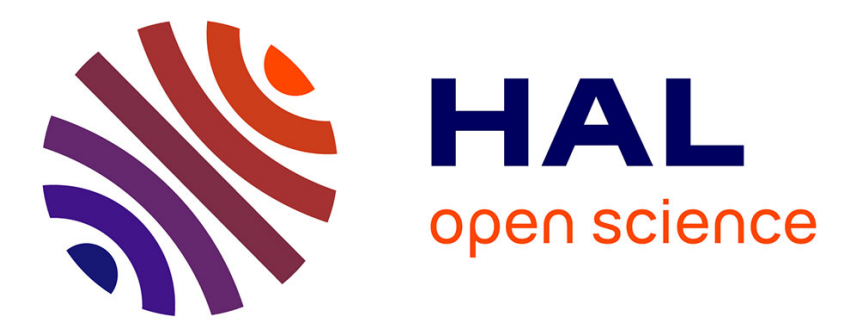

\title{
Medieval Silver Production around Sijilmâsa, Morocco
}

Sandrine Baron, M. Souhassou, François-Xavier Fauvelle

\section{To cite this version:}

Sandrine Baron, M. Souhassou, François-Xavier Fauvelle. Medieval Silver Production around Sijilmâsa, Morocco. Archaeometry, 2020, 62 (3), pp.593-611. 10.1111/arcm.12546 . hal-03001994

\section{HAL Id: hal-03001994 \\ https://hal.science/hal-03001994}

Submitted on 12 Nov 2020

HAL is a multi-disciplinary open access archive for the deposit and dissemination of scientific research documents, whether they are published or not. The documents may come from teaching and research institutions in France or abroad, or from public or private research centers.
L'archive ouverte pluridisciplinaire HAL, est destinée au dépôt et à la diffusion de documents scientifiques de niveau recherche, publiés ou non, émanant des établissements d'enseignement et de recherche français ou étrangers, des laboratoires publics ou privés. 


\section{Author Query Form}

\section{Journal: Archaeometry Article: arcm_12546}

Dear Author,

During the copyediting of your paper, the following queries arose. Please respond to these by annotating your proofs with the necessary changes/additions.

- If you intend to annotate your proof electronically, please refer to the E-annotation guidelines.

- If you intend to annotate your proof by means of hard-copy mark-up, please use the standard proofing marks. If manually writing corrections on your proof and returning it by fax, do not write too close to the edge of the paper. Please remember that illegible mark-ups may delay publication.

Whether you opt for hard-copy or electronic annotation of your proofs, we recommend that you provide additional clarification of answers to queries by entering your answers on the query sheet, in addition to the text mark-up.

\begin{tabular}{|c|c|c|}
\hline Query No. & Query & Remark \\
\hline Q1 & $\begin{array}{l}\text { AUTHOR: Please verify that the linked ORCID } \\
\text { identifiers are correct for each author. }\end{array}$ & \\
\hline Q2 & $\begin{array}{l}\text { AUTHOR: Please confirm that forenames/given names } \\
\text { (blue) and surnames/family names (vermilion) have } \\
\text { been identified correctly. }\end{array}$ & \\
\hline Q3 & $\begin{array}{l}\text { AUTHOR: "Ibn Zohr University of Taroudant, French } \\
\text { Ministry of Foreign Affairs, Federal University of } \\
\text { Toulouse, Centre National de la Recherche } \\
\text { Scientifique" was identified as funder in the supplied } \\
\text { metadata, however, this funder was not mentioned in } \\
\text { the acknowledgments or funding information section. } \\
\text { Please insert the appropriate text for this funder, or } \\
\text { confirm that this is to be deleted from the funders list. }\end{array}$ & \\
\hline Q4 & $\begin{array}{l}\text { AUTHOR: Can "less" be used here instead of "little" and } \\
\text { retain meaning? }\end{array}$ & \\
\hline Q5 & $\begin{array}{l}\text { AUTHOR: "Levresse et al., } 2016 \text { " is cited in text but not } \\
\text { provided in the reference list. Please provide details in the } \\
\text { list or delete the citation from the text. }\end{array}$ & \\
\hline Q6 & $\begin{array}{l}\text { AUTHOR: "Milot et al., } 2018 \text { " is cited in text but not } \\
\text { provided in the reference list. Please provide details in } \\
\text { the list or delete the citation from the text. }\end{array}$ & \\
\hline
\end{tabular}




\begin{tabular}{|c|c|c|}
\hline Query No. & Query & Remark \\
\hline Q7 & $\begin{array}{l}\text { PE: Harvard style explains that journal entries be } \\
\text { presented as vol. X, no. X, pp. X-XX, and edited books } \\
\text { should be editor name, then title, with page numbers } \\
\text { last. Please advise. }\end{array}$ & \\
\hline Q8 & $\begin{array}{l}\text { AUTHOR: "Garenne-Marot \& Mille, } 2007 \text { " has not been } \\
\text { cited in the text. Please indicate where it should be cited } \\
\text { or delete from the Reference List. }\end{array}$ & \\
\hline Q9 & $\begin{array}{l}\text { AUTHOR: Please provide publisher information and } \\
\text { page numbers }\end{array}$ & \\
\hline Q10 & $\begin{array}{l}\text { AUTHOR: Figures are assumed to be colour online only. } \\
\text { If you would like it to appear in colour both in print and } \\
\text { online, please complete and return a colour work } \\
\text { agreement form. Please download this from http:// } \\
\text { onlinelibrary.wiley.com/journal/10.1111/(ISSN)1475- } \\
\text { 4754/homepage/ARCM_CWA_Form_2015.pdf }\end{array}$ & \\
\hline
\end{tabular}

Please confirm that the funding sponsor list below was correctly extracted from your article: that it includes all funders and that the text has been matched to the correct FundRef Registry organization names. If a name was not found in the FundRef registry, it may not be the canonical name form, it may be a program name rather than an organization name, or it may be an organization not yet included in FundRef Registry. If you know of another name form or a parent organization name for a "not found" item on this list below, please share that information.

\begin{tabular}{|l|l|}
\hline FundRef Name & FundRef Organization Name \\
\hline Centre National de la Recherche Scientifique & Centre National de la Recherche Scientifique \\
\hline Federal University of Toulouse & not found \\
\hline French Ministry of Foreign Affairs & not found \\
\hline Ibn Zohr University of Taroudant & not found \\
\hline GET laboratory (CNRS, Toulouse) & not found \\
\hline $\begin{array}{l}\text { Thierry Aigouy (GET, CNRS laboratory in } \\
\text { Toulouse) }\end{array}$ & not found \\
\hline Ibn Zohr University of Taroudant in Morocco & not found \\
\hline $\begin{array}{l}\text { Federal University of Toulouse (Idex } \\
\text { project), }\end{array}$ & not found \\
\hline French Ministry of Foreign Affairs (MAEDI) & not found \\
\hline $\begin{array}{l}\text { Centre National de la Recherche Scientifique } \\
\text { (CNRS) }\end{array}$ & Centre National de la Recherche Scientifique \\
\hline
\end{tabular}




\title{
MEDIEVALSILVER PRODUCTIONAROUND SIJILMÂSA, MOROCCO*
}

\section{S. BARON† ID}

CNRS, UMR 5608, Laboratoire des Travaux et Recherches Archéologiques sur les Cultures, les Espaces et les Sociétés, Université de Toulouse Jean-Jaurès, Maison de la Recherche, 5 allées Antonio-Machado F-31 058 Toulouse Cedex 09, France

\section{SOUHASSOU}

Faculté Polydisciplinaire de Taroudant, Ibn Zohr University, Hay El Mohammadi (Lastah), B. P 27183000 Taroudant, Morocco and CNRS, UMR 5608, Laboratoire des Travaux et Recherches Archéologiques sur les Cultures, les Espaces et les Sociétés, Université de Toulouse Jean-Jaurès, Maison de la Recherche, 5 allées Antonio-Machado F-31 058 Toulouse Cedex 09, France

\section{F.-X. FAUVELLE}

Collège de France, Paris, France

\begin{abstract}
Sijilmâsa (south-east Morocco) was one of the most strategic cities in a far-reaching exchange network, that is, the trans Saharan trade, linking the Maghreb with West Africa during the medieval period (from the $8^{\text {th }}$ to the $15^{\text {th }}$ century CE). It was also one of the most important gold and silver monetary workshops at the time. If gold came from West Africa, we know from written sources that silver was produced in Morocco, although archaeological evidence of silver mining and smelting has remained elusive. Thanks to a thorough analysis of the lead isotopic data from silver mining districts in Morocco and from ores and slags of our study, we were able to refine the tracing of our materials and provide tangible evidence of medieval mining in the close hinterland of Sijilmâsa city.
\end{abstract}

KEYWORDS: SIJILMÂSA, SILVER, PB (LEAD) ISOTOPES, MINES AND SLAGS, TRANSSAHARAN TRADE

\section{INTRODUCTION}

A far-reaching exchange network developed across the Sahara from the eighth century CE following the conquest of North Africa by the Arabs (Austen 2010; Fauvelle 2018). This Trans-Saharan trade linked North Africa with West Africa across the desert. One consequence of these activities was the flourishing of trading cities and entrepôts on both sides of the Sahara. Of these, Sijilmâsa (in the south-eastern region of Morocco, in the oasis of Tafilalet) was one of the most important and certainly the most famous. As documented mainly by medieval Arabic written sources (Levtzion and Hopkins 2000), it was a crossroads for caravans of camels crossing the Sahara in both directions. Moreover, because Arabic coins were usually stamped with both the date and the name of the place where they were struck, we know that one of most important gold and silver monetary workshops in North Africa were run in the city.

*Received 19 September 2019; accepted 7 February 2020

†Corresponding author: email sbaron@univ-tlse2.fr

(C) 2020 University of Oxford 
In terms of goods exchanged along these Trans-Saharan routes, it is well established that while gold and slaves went north, copper-based materials went south. Sijilmâsa was one of the North African outlets of West African gold (e.g Gondonneau et al. 2000; Roux and Guerra 2000; Gondonneau and Guerra 2002; Nixon et al. 2011). Numerous gold coins (called dīnār in Arabic, "dinars") were minted there from the $10^{\text {th }}$ to the $14^{\text {th }}$ century (Messier 1973; Roux and Guerra 2000; Gondonneau and Guerra 2002). Dinars minted in Sijilmâsa were known throughout the entire medieval Islamic world for their fineness (Cipolla 1956). On the other hand, it is also accepted that copper and copper alloys in the form of metal bars or manufactured objects were traded southward to West Africa (Monod 1969; Gouchet et al. 1976; Garenne-Marot et al. 2003).

Although the direction of the circulation of gold and copper is relatively well known despite some uncertainties concerning the precise location of the mines, that of silver remains a mystery. Silver coins (called dirham in Arabic, "dirhams") were minted in Sijilmâsa alongside gold coins, but the origin of the silver has remained a matter of conjecture. Some Arabic texts suggest that conflicts took place between medieval Moroccan polities for the control of silver production and transformation (Rosenberger 1970a). Thus, as in Europe in the same period (Bailly-Maitre

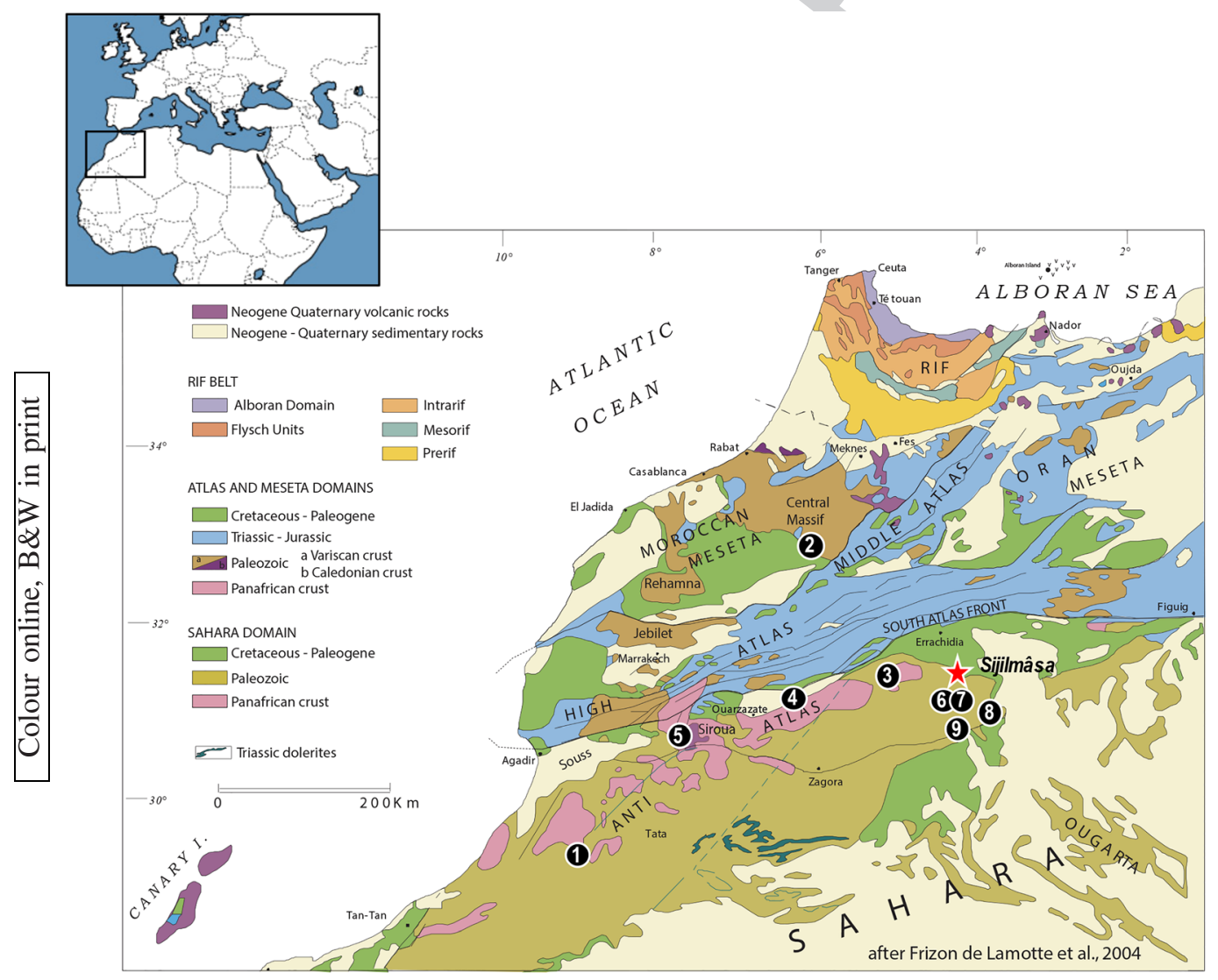

Q10 Figure 1 Moroccan geological structural units and location of the main Pb bearing mines. 1- Jebel Addana, 2- Jebel Aouam, 3- Bou Madine, 4- Imiter, 5- Zgounder, 6- Bou Maiz, 7- Gaouz, 8- Mfis, 9- Tadaout (modified from Frizon de Lamotte et al. 2004). [Colour figure can be viewed at wileyonlinelibrary.com] 
2002), mining resources and related metallurgical sites were certainly of strategic importance even though the precise relationship between a silver mining area and a political or economic power has yet to be demonstrated in Morocco.

At present, archaeological evidence for gold and silver mining and workshop activity related to the trans-Saharan trade remains elusive. Although numerous elemental analyses exist for copper-base materials (e.g. Garenne-Marot et al. 2003), they are none for gold and silver-base ones (El Ajlaoui 1994; Magnavita and Mertz-Kraus 2019). An exception, as far as gold is concerned, comes from Tadmekka, in current-day Mali, a medieval entrepôt on the southern edge of the Sahara, where, according to the authors interpretation, small pieces of mould or crucible would be an evidence for gold-fire treatment to elaborate some "unstamped" gold dinars (Nixon et al. 2011; Rehren and Nixon 2014).

As yet, no evidence for mining and metallurgy from medieval Morocco - and medieval North Africa in general - (such as slags or waste heaps/tailings materials) has been excavated, dated, and studied by combining archaeology, geology, and geochemistry. Some slag studies have been carried out for on North African materials, but they mainly concern iron metallurgy from the Phoenician and Roman periods (Tylecote 1980; Keesmann 2001; Niemeyer 2001; Hourri et al. 2017), which are not related to the historical context presented here.

In 2013, during excavations conducted in Sijilmâsa by a French-Moroccan team led by F.-X. Fauvelle and E. Erbati (Fauvelle et al. 2014, 2018), some non-ferrous slags (highly recognizable, visually, compared to iron slags) were recovered and dated to around the $10^{\text {th }}$ century. By the mean of (a) systematic geological survey on lead silver deposits closest to the city, (b) lead $(\mathrm{Pb})$ isotopes measurements on slags and ores, and (c) petrographic and mineralogical studies on slags, our study has highlighted a geochemical link between Sijilmâsa's slags and the argentiferous lead mines found in the vicinity of the medieval city.

\section{GENERAL GEOLOGICAL CONTEXT OF THIS STUDY}

Morocco is divided into five geological domains: (from north to south) the Rif, the Meseta, the Atlas (high and middle), the Anti-Atlas, and the Sahara (Fig. 1). The mining activities (modern F1 and ancient ones) and occurrences deposits (silver, gold, copper and lead) are located in metallogenetic provinces. Each of them is defined in relation to geodynamic events. Some mineralizations are linked with the Archean craton ( $>2500 \mathrm{Ma})$, the Precambrian episodes-the Eburnean ( 2000 Ma) and the Pan African orogenesis $(\sim 600 \mathrm{Ma})$, the Hercynian cycle $(\sim$ $400 \mathrm{Ma}$ to $\sim 250 \mathrm{Ma}$ ) and the Alpine one ( 250 Ma to today). With the exception of Jebel Aouam (in central Morocco), all the mining districts considered in our study are part of the Anti-Atlas domain, more specifically the eastern portion of it (Fig. 1). The Anti-Atlas domain, which is $750 \mathrm{~km}$ long with a WSW-ESE direction, that is, from the Atlantic Ocean to the Tafilalet region (Fig. 1), is included in the Pan African orogenic belt. The Anti Atlas represents the main structural domain of southern Morocco: it is composed of Proterozoic ( 2500 Ma to $540 \mathrm{Ma})$ inliers distributed along two major fault zones (South Atlas Fault, and Central Anti-Atlas Fault) and covered by Ediacaran formations (Late Neoproterozoic to Paleozoic i.e. 635 Ma to 540 Ma; Gasquet et al. 2005). This area possesses a number of important lithostratigraphic units that have been affected by numerous geological events. Thus, it is quite difficult to determine a relative chronology and to interpret the geological ages through isotopes measurements (Levresse 2001; Tuduri 2005). However, there is a scholarly consensus on the existence of a Paleoproterozoic to mid-Neoproterozoic basement $(\sim 2500 \mathrm{Ma}$ to $770 \mathrm{Ma})$ and a late Neoproterozoic to Cambrian cover ( $635 \mathrm{Ma}$ to $485 \mathrm{Ma})$. 
The Anti-Atlas Mountains possess numerous silver-rich lead ore resources. Some mining areas are actually called "Portuguese mining works" by local people (a designation not to be taken at face value), and some "old mining works" were often mentioned and orally conveyed by engineers working on modern exploitations. The partial descriptions of such discoveries are often preserved in anonymous reports of mining companies and remain difficult to access.

\section{MATERIALS}

\section{Medieval silver mines in Morocco}

During the medieval and early modern periods, both Arabic and Spanish texts mention that Moroccan mines were exploited for silver (Rosenberger 1970a, 1970b, 1970c). They are sometimes mentioned in connection with Sijilmâsa, whose authorities (i.e., the Sultan) levied a tax of 1/5 (named the "quint" tax) on silver (Colin 1954; Rosenberger 1964, 1970a; Monteil 1968). These mines can be provisionally equated with those of Zgounder (native silver), Imiter (native silver), and Jebel Aouam (lead and silver) (Fig. 1) (Rosenberger 1970a, 1970b). The legal status of these mines is not known. Nevertheless, the Sultan would seem to apply a certain right/power to them (Rosenberger 1970a). This suggests that these mines had certainly a particular status and were linked to the authorities. Scattered archaeological discoveries made at these three mines by mining engineers include ancient mining works, noria, waste heaps, slags, furnace pieces, stone grinders, tools, and metallurgical materials, though unfortunately without reliable archaeological context (Rosenberger 1970b). A radiocarbon analysis carried out on a wood sample from the mine of Jebel Aouam indicates medieval exploitation of ore (Saadi 1971), although, again, no information is provided on the archaeological context of the sample. These mines would have been also the location of silver mint workshops: numismatic data bear witness to a mint at "Mrirt," close to the Jebel Aouam mine (Rosenberger 1964) and another at "Todgha," another ancient site likely not far from today's Imiter mine (Colin 1936b; El Ajlaoui 1994). A mint may have been located at the fortification in Zgounder mining area (Colin 1936a; Colin 1954). All this information should be taken with caution because not related to relevant field evidence tha is, no archaeological plans and no global chronological context, just some observations, punctual dating, and brief drawings before modern mining. Thus, archaeological, literary and numismatic evidence are heterogeneous and cannot help locating precisely the mints. However, for our purpose, the evidence is enough here to define an area (i.e. from Zgounder, Imiter to Jebel Aouam) where both mines and smelting workshops were observed. It should be noted, however, that these observations in Morocco seem to be in line with some archaeological data on both the ancient mining/metallurgical technics and the spatial location of mines and mints during medieval periods in Europe (e.g. Bompaire and Sarah 2018).

In addition to silver, the medieval Jebel Addana mines were also an important source of copper. These mines seem to have been connected not with Sijilmâsa but with Tamdult, another important medieval entrepôt and mining centre (Rosenberger 1970c). Indeed, numerous slags were recovered during prospection in Tamdult, but they have yet to be studied (Cressier 2004).

Other, possibly less significant, mines cited in Spanish and Arabic texts can be assumed to be located closer to Sijilmâsa (Rosenberger 1970b). They can tentatively by identified as those of Bou Madine, Bou Maiz, Gaouz, Mfis, and Tadaout, which are still active today (Muqaddasi 1950; Zigari 1963; Rosenberger 1970b; Fig. 1). However, despite their geographical proximity - they are located in a radius of just a few dozen kilometres from the site - a direct connection between these mines and Sijilmâsa has never been proven until now. 


\section{The ores typology in close hinterland of Sijilmâsa}

The mineralized ores of Tadaout, Mfis, Bou Maiz, and Gaouz have recently been exploited for lead and silver, and currently are for barite. The mineralized structures exhibit two orientations, that is, N-S and W-E. The latter is largely dominant. Most lodes are several kilometers in length with a thickness of more than 3 meters. The enclosing rocks are pelitic sandstone and are more granitic in the Mfis mining area. The mineralization is composed of galena and barite associated with quartz and calcite. The mineralization hosts also the presence of pyrite, chalcopyrite, and malachite. Three ore assemblages of paragenesis were identified during our surveys. The first one is composed of galena included in a strongly oxidized pelitic sandstone (Fe-rich); the oxidation effect has produced some nodules of galena (called "patate" in French, "potatoes," by local people). The second paragenesis is composed of galena associated with barite and sometimes with calcite; the galena could be also scattered in barite. The last paragenesis is composed of galena associated with calcite and quartz in a ferruginous enclosing rock.

\section{Archaeological context of slags uncovered in Sijilmâsa}

Sijilmâsa is a medieval Islamic city located in the oasis of Tafilalet, in south-east Morocco. The ruins of the site are located in the suburbs of the current town of Rissani. Following scanty and ill-documented excavations conducted in the 1960s and 1970s, American-Moroccan team spent

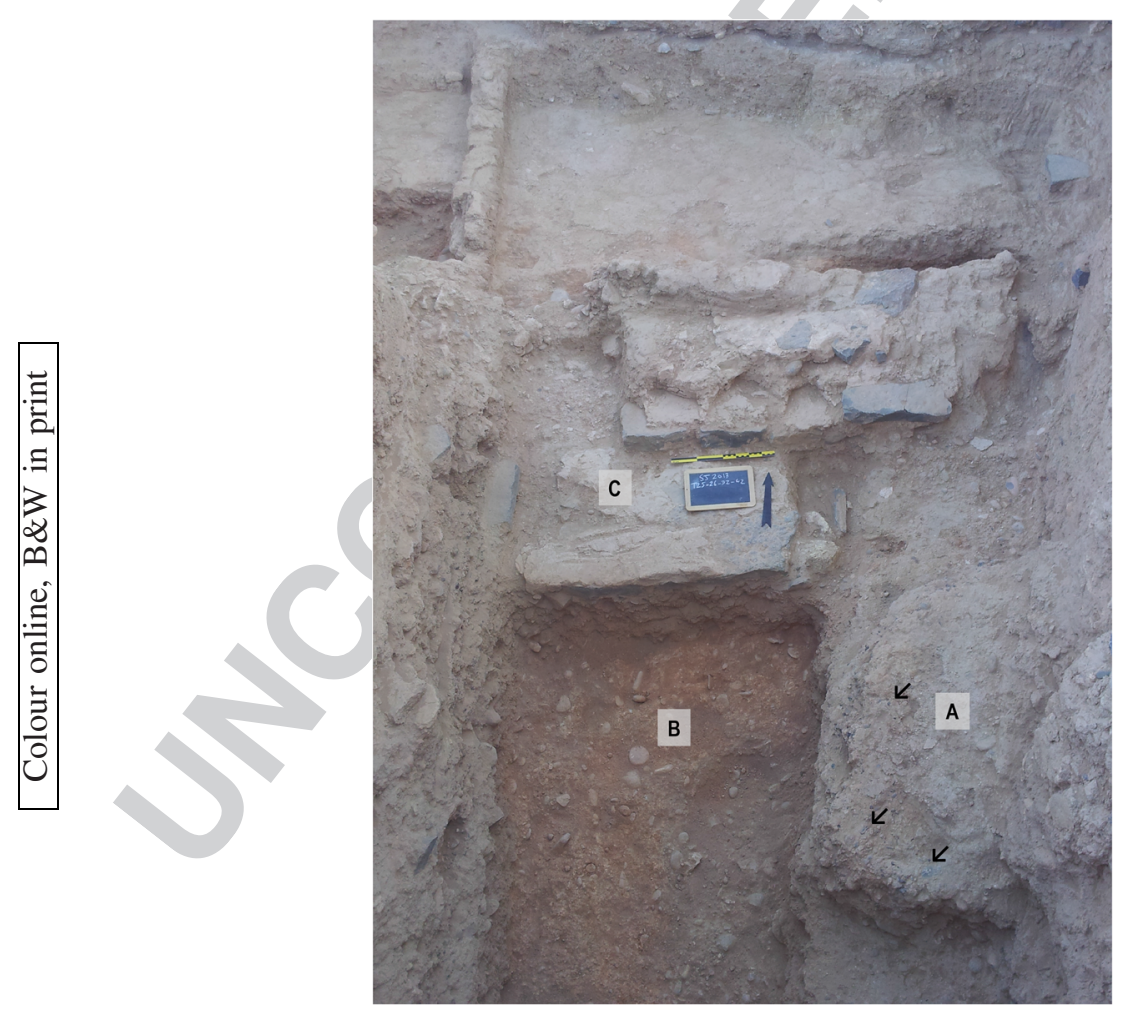

Figure 2 Sijilmâsa, sector T25. A: Floor AU 11 (arrows show the slags). B: Local test pit in floor UA 11 down to the bedrock (orange color). C: Wall made of schist blocks which UA11 abuts (CMission Archéologique à Sijilmâsa, 2013). [Colour figure can be viewed at wileyonlinelibrary.com] 
five archaeological seasons there in the 1990s (Messier 1997; Messier and Miller 2015), and a French-Moroccan mission took over from 2012 on (Fauvelle et al. 2014). In addition to uncovering high and thick remnants of surrounding walls belonging to several periods from the $10^{\text {th }}$ to the $15^{\text {th }}$ century CE (Fauvelle et al. 2018), the excavations yielded built remains of various types and functions-a mosque and residential complex; dwellings; hydraulic structures such as basins, pipes and latrines-associated with artifacts, mostly ceramics. The dominant architectural feature in the excavated areas is rammed earth (called pisé in French and tabiya in Arabic), a local construction technique in Southern Morocco, still commonly used today to build fortified quadrangular villages called ksur (sing. ksar). Subject to intense erosion, this material requires constant maintenance and repairs (Boussalh et al. 2005), as well as periodic abandonment and rebuilding of the entire construction (Darles et al. 2016), a cycle that may explain the alternation of phases of occupation and abandonment observed in the stratigraphic sequence (Fauvelle et al. 2018). Only very small numbers of luxury or prestige items were found by the archaeologists, possibly due to the poor preservation of the built structures or to centuries of looting (Fauvelle et al. 2014). Certainly, finds of gold were very rare: only a few medieval gold coins and one tiny ring made of gold filigree (Messier 1997). A series of basins connected by canalizations was interpreted as a facility to wash mineral ores (Messier 1997), although this interpretation remains dubious both on functional grounds and because no ore was found there (Soubira et al. 2015). Furthermore, investigators found no structure that could plausibly have been a gold mint nor devices such as molds and crucibles. The near absence of gold artefacts and tools related to gold transformation and/or minting is at odds with the abundance of written

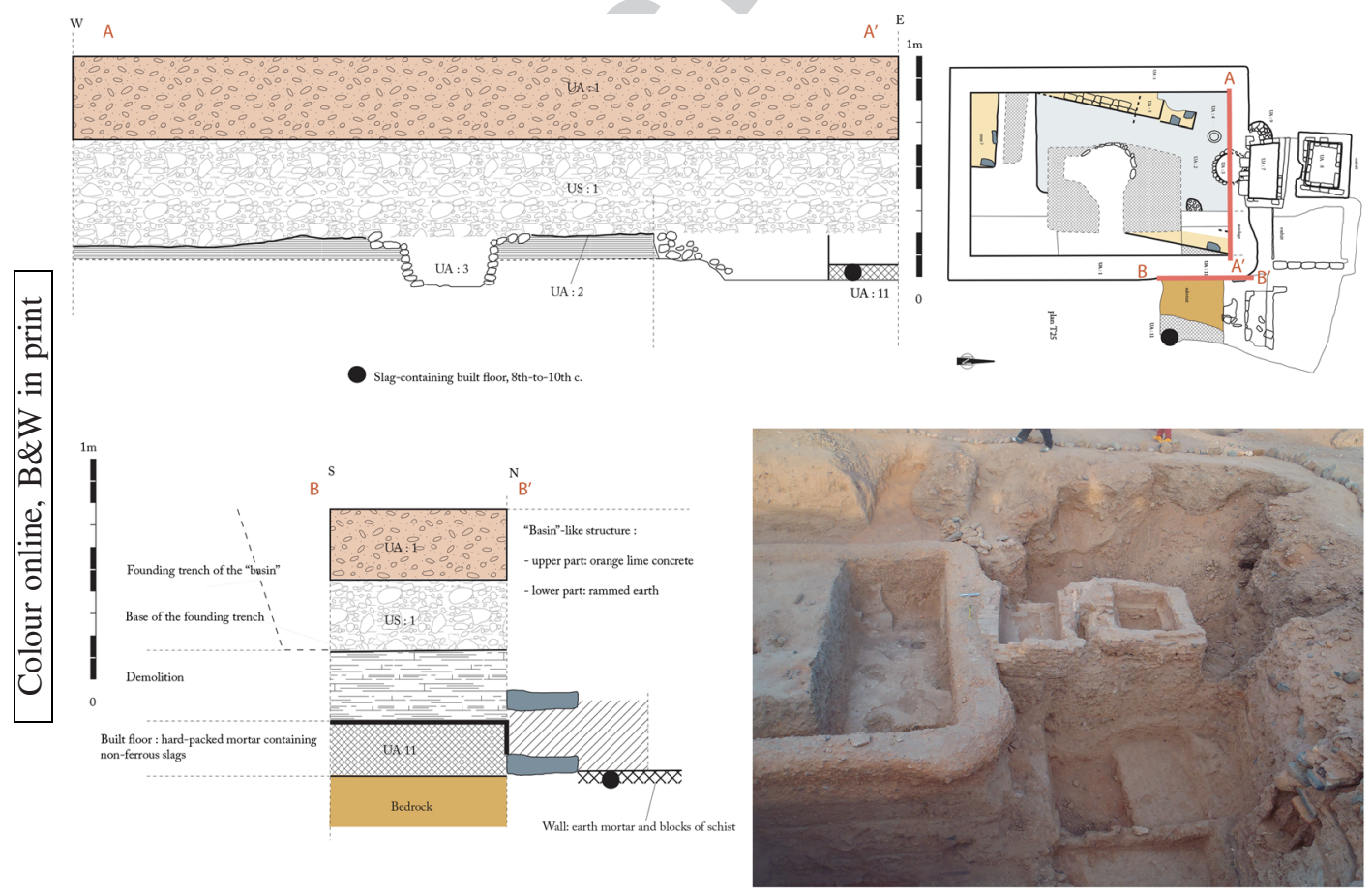

Figure 3 Picture, plan, stratigraphic sections (AA' and BB') of sector T25 (CMission Archéologique à Sijilmâsa, 2013). [Colour figure can be viewed at wileyonlinelibrary.com] 
and numismatic evidence testifying to Sijilmâsa's role as a gold emporium. It is probably the most striking paradox of the 'City of Gold'.

Interestingly, the case for silver is different. Digging deeper in a trench (T25) previously excavated by the American-Moroccan team that had uncovered a hydraulic complex (Messier 1997), the French-Moroccan team found a well-preserved floor made of a very compact sand and silt mortar containing lime (Fig. 2). As is often the case with similar floors belonging to the earliest F2 phases of occupation elsewhere on site, this floor $(\mathrm{AU}=$ Architectural Unit 11) was reinforced with mineral components of homogenous module that were sunk into it. In this case, they were found to be small cobbles ( $\max 3 \mathrm{~cm}$ ), which immediately turned out to be non-ferrous slags, a fact that was confirmed by analyses (see 5.1 Results Section). Because the excavators did not dismantle this archaeological feature, no quantification of the slags could be made, but there is no question that slags were voluntarily used as the exclusive mineral component of this floor. The rationale behind the use of slags as a construction material, which, to the best of our knowledge, has no parallel in Sijilmâsa or elsewhere in the Islamic world, remains unclear, and we cannot assess whether slags were used for technical reasons or opportunistically. Nevertheless, the presence of these slags embedded in an early architectural feature in Sijilmâsa is, we believe, an opportunity to date them and prove a relationship between the city and a mine. Indeed, the slags either were waste products of a transformation process carried out in the city from ores coming from the mine, or were brought to the city from a mine or its workshop.

In terms of stratigraphy (Fig. 3), the slag-containing floor (thickness: $17 \mathrm{~cm}$ ) sits atop a prep- F3 aration layer $(32 \mathrm{~cm}$ ) made of an earth mortar containing cobbles (this latter layer was considered to belong to the same floor, AU 11) which was laid directly on the bedrock. AU 11 itself abuts a wall base made of schist blocks and earth mortar, which in turn was found, at its western end, to overlay another floor (AU 2), made of thick and extremely hard lime concrete. This floor yielded two radiocarbon dates: SIJ-2013-E1 (Beta 396369) $=1220+/-30$ BP $=$ Cal CE 690-750, 760$885(2 \sigma)$ (micro-charcoal coming from within the floor); SIJ-2013-E6 (Beta 396370) $=1110+/$

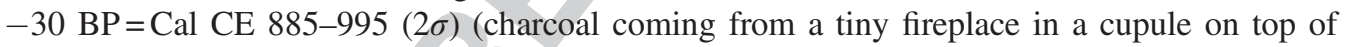
the floor). Though the stratigraphic relationship between floors AU 11 and AU 2 was not observed, the chronological attribution of floor AU 11 is secure: it cannot be later that the end of the $10^{\text {th }}$ century $\mathrm{CE}$.

\section{METHODS}

We carried out systematic geological survey in the mining districts close to Sijilmâsa, namely Mfis, Tadaout, Gaouz, Bou Maiz, Bou Madine, and Imiter. Because no mineralogical and geochemical data were available for Mfis, Tadaout, Gaouz, and Bou Maiz, and also because the geology of Morocco is very complex, a systematic ores sampling $(\mathrm{n} \sim 80)$ was conducted according to the three assemblages of paragenesis observed during fieldwork, in order to outline the lead isotopic signatures of these areas.

Bulk multi-elemental analyses on slags were obtained commercially from ALS Global (www. alsglobal.com) to measure slag matrix composition (normalised to 100\%) but also to assess the $\mathrm{Pb}$ isotopes measurements. Several slags samples were cut into thin sections at GET laboratory (CNRS, Toulouse, France). A first identification of the mineralogical composition of the samples was performed by microscopic observations in reflected and transmitted light in the TRACES and GET laboratories (CNRS, Toulouse, France). A selection of samples was collected for more detailed mineralogical investigations by scanning electron-microscopy with energy dispersive 
spectroscopy (SEM-EDS) and electron microprobe analyses, performed at GET laboratory and the Raymond Castaing Micro-Characterisation Centre (CNRS, Toulouse, France), respectively.

66 ores samples (galena) and six slags samples were chemically processed for lead $(\mathrm{Pb})$ isotopic analyses in a Class-1000 clean room in Toulouse (GET, CNRS laboratory, France). All reagents used were double distilled in PFA stills. Galena's and slags Pb isotopic compositions were measured with a MC-ICP-MS (Neptune type), following the procedure reported by Baron et al. (2009). The values used for reference are those of NIST-SRM $981 \mathrm{~Pb}$ as reported by

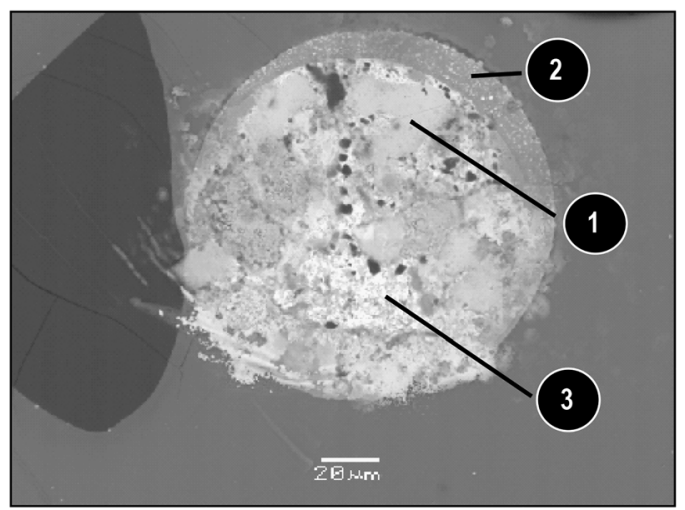

$1: \mathrm{Ag}-\mathrm{Pb}-\mathrm{Cu}-\mathrm{Sb}-\mathrm{Au}$

2 : Chalcocite

$3:$ Lead metal

Clear slag (SIJ-14-SC6)

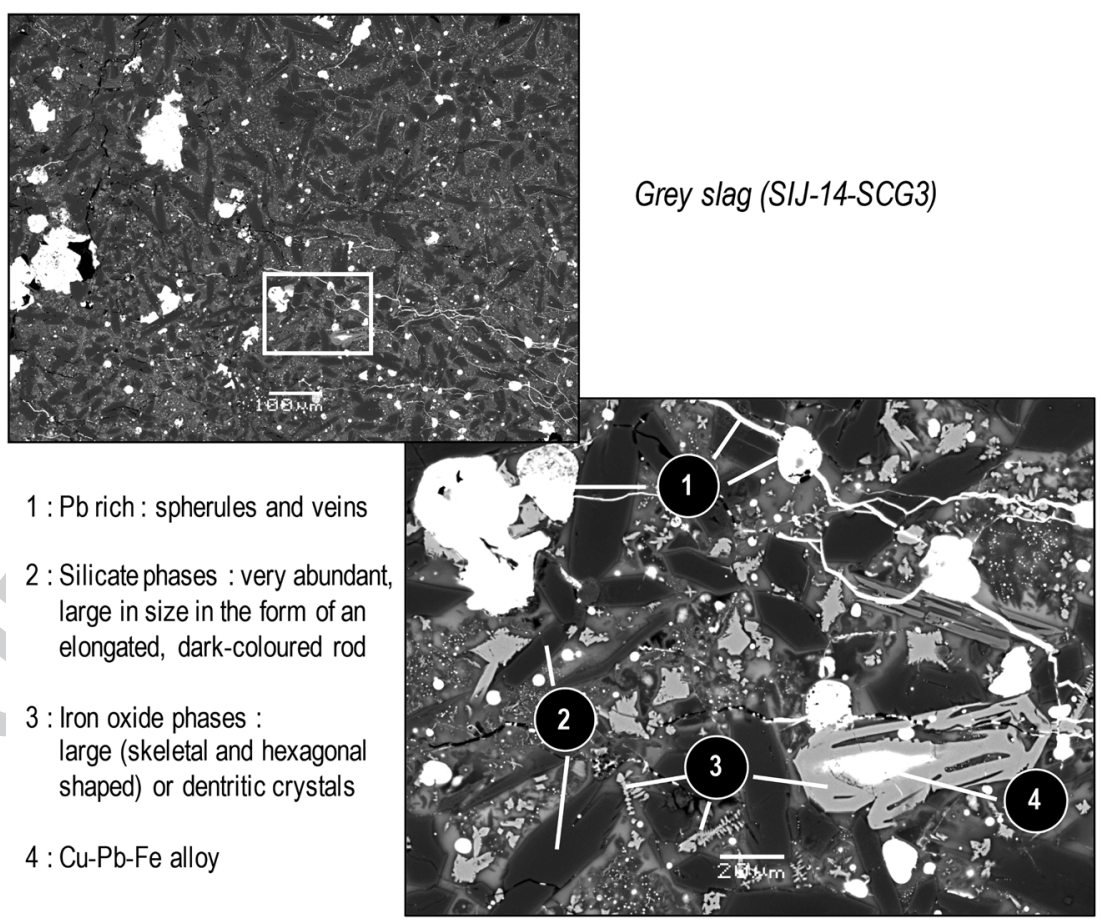

Figure 4 SEM pictures showing the mineralogy of clear and grey slags (Samples SIJ-14-CS6 and SIJ-14-SCG3 respectively). 
Thirlwall (2002). The NIST-SRM $981 \mathrm{~Pb}$ precision and accuracy of all the reported isotopic ratios are better than $100 \mathrm{ppm}(2 \sigma)$.

$\mathrm{Pb}-\mathrm{Pb}$ model ages were calculated using a two-stage model (Stacey and Kramers 1975) and adapted for archaeological issues (Albarède et al. 2012). The measured $\mathrm{Pb}$ isotopic data of ores and slags, associated with their calculated $\mathrm{Pb}-\mathrm{Pb}$ model ages $\left(\mathrm{T}, \mu,{ }_{K}\right)$, are reported in Table $\mathrm{S} 1$.

At Gaouz, we were able to collect a micro-charcoal from the surface of a slag with adhering technical ceramic (presumably a furnace wall fragment). The charcoal sample (SIJ-2016-E15) was analysed by Beta Analytic (Beta 451470).

\section{RESULTS}

\section{Chemical and mineralogical compositions of slags uncovered in Sijilmâsa}

The bulk multi elemental analyses (normalised to $100 \%)$ of the whole slags $(n=14)$ gave a median value of 45.9 wt. $\%$ of $\mathrm{SiO}_{2}, 9.8$ wt.\% of $\mathrm{Al}_{2} \mathrm{O}_{3}, 7.5$ wt. $\%$ of $\mathrm{Fe}_{2} \mathrm{O}_{3}, 12.2$ wt.\% of $\mathrm{CaO}$, 2.4 wt. $\%$ of $\mathrm{MgO}, 3.8$ wt.\% of $\mathrm{Na}_{2} \mathrm{O}, 1.9$ wt.\% of $\mathrm{K}_{2} \mathrm{O}, 13.5$ wt. $\%$ of $\mathrm{Pb}, 0.27$ wt. $\%$ of $\mathrm{Cu}$, and $90.2 \mathrm{ppm}$ of $\mathrm{Ag}$. The chemical composition of slags from Sijilmâsa suggests that these byproducts are coming from a non-ferrous metallurgical process, namely the reduction of silver-rich lead ores (argentiferous ores whose copper content comes from the mineralization as observed during our geological prospecting). The global positive correlation between the alkali elements of the slag matrixes suggests a common origin, that is, the slags come from the same type of ore. The reduction slag samples from Sijilmâsa can be divided into two groups according to their bulk chemical composition, mineralogical aspect and composition identified by microscopic observations, SEM-EDS, and electron microprobe analyses.

Two kinds of slags were identified based on their colour (clear or grey), which are derived from their iron oxide content, that is, the clear slags highlight a median $\mathrm{Fe}$ content of 25.6 wt. \% $\left(\mathrm{Fe}_{2} \mathrm{O}_{3}\right)$, whereas the grey ones highlight a median Fe content of 5.3 wt.\% $\left(\mathrm{Fe}_{2} \mathrm{O}_{3}\right)$. In the two kinds of slags, the $\mathrm{Pb}$ is in the form of metal and located in the prills (which are in inclusions with various sizes), in the venules, and in the matrix phase (Fig. 4). In more details, F4 the two slags exhibit some mineralogical differences. The clear slags are very vitreous $(\mathrm{Pb}$ content in matrix phase is less than $30 \%$ ) and contain rare mineral phases like silicate phases and chalcocite (copper sulphide). The grey slags are little vitreous ( $\mathrm{Pb}$ content in matrix phase is more Q4 than $35 \%$ ), better crystallized than the clear slags, and highlight new mineral phases like numerous silicate and iron oxide phases. Numerous metallic prills, in all the analysed slags, highlight the presence of lead, silver, and copper metal (Fig. 4).

\section{Gaouz charcoal dating}

The charcoal sample (SIJ-2016-E15) yielded the uncalibrated result: $1340+/-30 \mathrm{BP}=\mathrm{Cal} \mathrm{CE}$ $650-690,750-760(2 \sigma)$. We acknowledge that there is a growing body of evidence (albeit poorly published) indicating that the $\mathrm{C}-14$ analysis of charcoal inclusions in slag tend to produce older dates (e.g. Gassmann and Schäfer 2018). The reason is not fully understood, but it could be caused by contamination either during the smelting or perhaps through mineralisation in the burial environment. However, in our case, the sample was not found buried but on the ground, and the micro-charcoal was found on the surface of the slag, in close contact with the technical ceramic fragment. In the current state of the literature, we cannot assess whether it is a weakening or reinforcing argument. 
Radiogenic Pb isotope composition and calculated model ages of ores and slags

The $\mathrm{Pb}$ signatures of ores from the close vicinity of Sijilmâsa present some homogeneous isotopic compositions: Tadaout, Mfis, Bou Maiz and Gaouz have $\mathrm{Pb}$ isotopic compositions ranging between 18.102 to $18.169,15.579$ to 15.624 and 38.123 to 38.322 for ${ }^{206} \mathrm{~Pb} /{ }^{204} \mathrm{~Pb},{ }^{207} \mathrm{~Pb} /{ }^{204} \mathrm{~Pb}$ and ${ }^{208} \mathrm{~Pb} /{ }^{204} \mathrm{~Pb}$ ratios, respectively. The Bou Madine ore $\mathrm{Pb}$ signature is $18.016,15.553$ and 37.807 for ${ }^{206} \mathrm{~Pb} /{ }^{204} \mathrm{~Pb},{ }^{207} \mathrm{~Pb} /{ }^{204} \mathrm{~Pb}$ and ${ }^{208} \mathrm{~Pb} /{ }^{204} \mathrm{~Pb}$ ratios respectively. The $\mathrm{Pb}$ signatures of ores from Imiter mine range between 18.123 to $18.147,15.557$ to 15.575 and 37.817 to 37.881 for ${ }^{206} \mathrm{~Pb} /{ }^{204} \mathrm{~Pb},{ }^{207} \mathrm{~Pb} /{ }^{204} \mathrm{~Pb}$ and ${ }^{208} \mathrm{~Pb} /{ }^{204} \mathrm{~Pb}$ ratios respectively.

The $\mathrm{Pb}$ signatures of slags from Sijilmâsa are also very homogeneous. Their $\mathrm{Pb}$ isotopic composition range between 18.076 to $18.155,15.590$ to 15.616 , and 38.136 to 38.284 for ${ }^{206} \mathrm{~Pb} /{ }^{204} \mathrm{~Pb},{ }^{207} \mathrm{~Pb} /{ }^{204} \mathrm{~Pb}$ and ${ }^{208} \mathrm{~Pb} /{ }^{204} \mathrm{~Pb}$ ratios respectively.

The $\mathrm{Pb}$ signatures of radiocarbon-dated slag sample SIJ-2016-E15 from Gaouz is 18.154, 15.579 and 38.160 for ${ }^{206} \mathrm{~Pb} /{ }^{204} \mathrm{~Pb},{ }^{207} \mathrm{~Pb} /{ }^{204} \mathrm{~Pb}$, and ${ }^{208} \mathrm{~Pb} /{ }^{204} \mathrm{~Pb}$ ratios respectively.
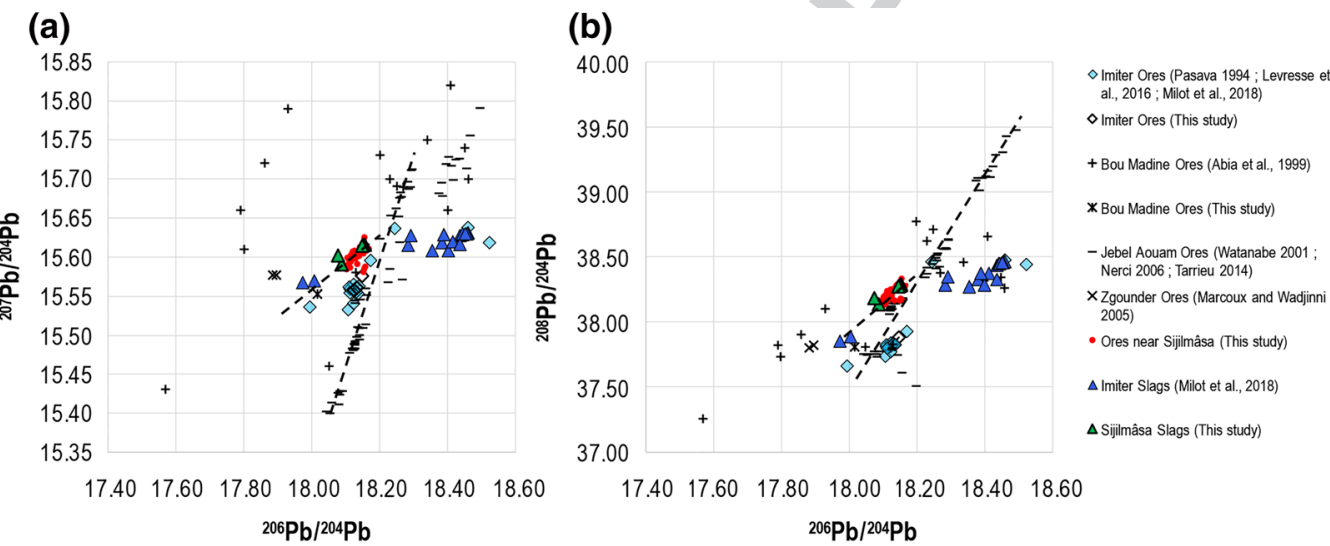

(c)

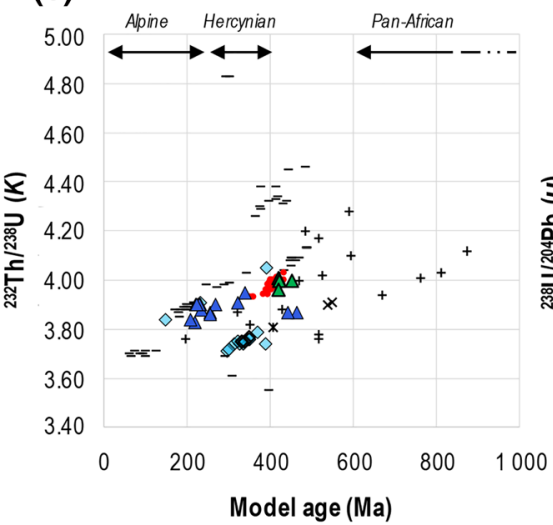

(d)

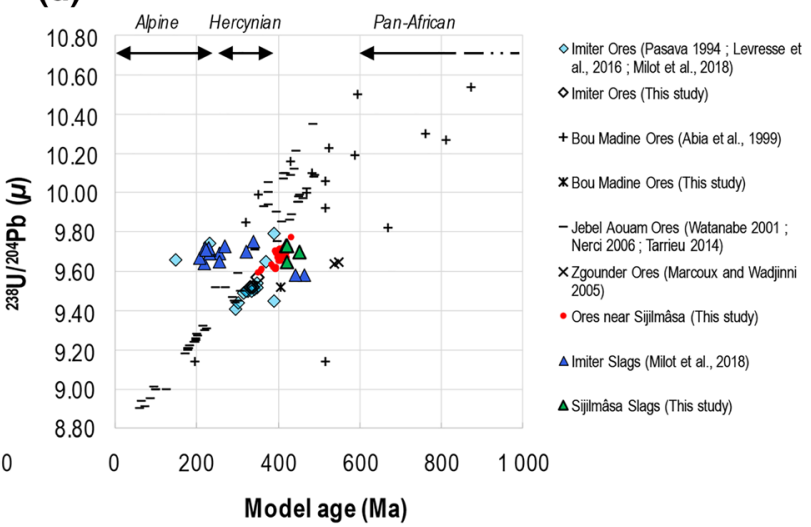

Figure 5 a) ${ }^{207} \mathrm{~Pb}{ }^{204} \mathrm{~Pb}$ versus ${ }^{206} \mathrm{~Pb}{ }^{204} \mathrm{~Pb}$, b) ${ }^{208} \mathrm{~Pb}{ }^{204} \mathrm{~Pb}$ versus ${ }^{206} \mathrm{~Pb}{ }^{204} \mathrm{~Pb}$, c) $\mathrm{Pb}$ model ages versus model ${ }^{232} \mathrm{Th}^{238} U\left({ }_{K}\right)$ and d) $\mathrm{Pb}$ model ages versus model ${ }^{238} U \mathrm{P}^{204} \mathrm{~Pb}(\mu)$ of ores from Imiter (Levresse et al., 2016, Milot et al., 2016 and this study), Bou Madine (Abia et al. 1999 and this study), Jebel Aouam (Watanaby, 2001; Nerci 2006; Tarrieu 2014), Zgounder (Marcoux and Wadjinni 2005), ores near Sijilmâsa (this study), and of slags from Imiter (Milot et al., 2016) and Sijilmâsa (this study). [Colour figure can be viewed at wileyonlinelibrary.com] 
The calculated $\mathrm{Pb}-\mathrm{Pb}$ models of ores and slags from our study thus demonstrate that the minerals were Palaeozoic, ranging from $\sim 330$ to $450 \mathrm{Ma}$. The mean T model age of ores from Imiter,

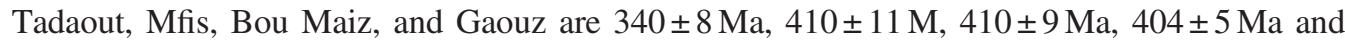
$360 \pm 2 \mathrm{Ma}$ respectively. The model age of ores from Bou Madine is $406 \mathrm{Ma}$ (one sample). The mean model age of slags from Sijilmâsa is $427 \pm 1 \mathrm{Ma}$, and model age of slag from Gaouz is $352 \mathrm{Ma}$ (one sample). The ${ }^{238} \mathrm{U} /{ }^{204} \mathrm{~Pb}$ ratio $(\mu)$ and ${ }^{232} \mathrm{Th} /{ }^{238} \mathrm{U}\left({ }_{K}\right)$ values, for the whole samples from this study, are ranging between 9.52 to 9.77 and 3.75 to 4.03 respectively.

\section{DISCUSSION}

Sijilmâsa is known from numismatic data to have struck silver coins and we now have archaeological and geochemical evidence that silver ore was transformed either at or in the vicinity of Sijilmâsa. Because the city (or its silver workshop) could have received its ore from multiple sources, it is necessary to discuss and interpret in detail the isotopic lead data from all potential mining sources, identify those sources and assess their respective potential contributions. The isotopic signatures of the Sijilmâsa slags are very homogeneous and similar to those of the nearest lead-silver mines. Nevertheless, the Sijilmâsa slags signatures are positioned within a vast isotopic field which encompasses various Moroccan silver mines (Fig. 5a,b). This might F5 suggest a potential averaging effect of the Sijilmâsa slags isotopic composition that could be due to mixing ores from several different silver mines. However, a deeper knowledge of the $\mathrm{Pb}$ isotopic signatures of ores (from literature and our results) and Sijilmâsa slags can provide a better understanding of this seeming mixing effect and attribute an eventual single source.

\section{Terms and conditions of ores implementation of silver mines}

Figure 5 reports the $\mathrm{Pb}$ signatures of ores from the silver mines surrounding Sijilmâsa versus the $\mathrm{Pb}$ signature of slags recovered from the site of Sijilmâsa proper (Fig. 5a,b). The corresponding calculated model ages both with isotopic $\mathrm{Pb}$ compositions on galena from literature and the present study are reported in Figure $5 \mathrm{c}$ and $\mathrm{d}$. The mining districts taken into consideration are Bou Madine, Imiter (ores and slags), Jebel Aouam, Zgounder, and lead-silver mines near Sijilmâsa city. The most heterogeneous $\mathrm{Pb}$ isotopic composition are from Jebel Aouam and Bou Madine. The wide extent of $\mathrm{Pb}$ isotopes from some mining districts, in classical $\mathrm{Pb} / \mathrm{Pb}$ diagrams, coupled with isotopic overlappings, reflect the strong complexity of the ores implementation through geological times (Fig. 5a,b). Indeed, the different ore sources has been implemented over a very long period of time (such as Bou Madine and Jebel Aouam mining districts; Fig. 5c, d). No isotopic data are available for the Jebel Addana mining district and related slags.

The polymetallic Jebel Aouam mining district was formed by successive magmatic-hydrothermal pulses, namely one at 295-280 Ma (porphyry-style-Au-W mineralisation) and another one at $254 \pm 16 \mathrm{Ma}$ (epithermal-style- $\mathrm{Pb}-\mathrm{Zn}-\mathrm{Ag}$ mineralisation; Watanabe 2002; Nerci 2006; Tarrieu 2014; Rossi et al. 2016). This produced a superposition of two independent mineralisation events as illustrated by the $\mathrm{Pb}$ isotopic signatures on Figure 5 ( $\mathrm{a}$ and $\mathrm{b}$ ). Calculated $\mathrm{Pb}-\mathrm{Pb}$ model age of Jebel Aouam, from some galena, indicates older ages ( 400-500 Ma) and high ${ }_{K}$ values $(>4.00)$, which are an indication of magmatic inheritance originating from melting Palaeozoic crustal rocks (Fig. 5c). Other galena are much younger $\left(<100 \mathrm{Ma}\right.$ ) with low ${ }_{K}$ values $(<3.80)$ (Fig. 5c), indicating multiple intrusions of Cordilleran-type calco-alkaline magmatism during the late Variscan to Permo-Triassic geological period (Michard et al. 2008; Rossi et al. 2016). The Pb-Pb model ages of slags from Sijilmâsa 
are quite similar to some galena ores from Jebel Aouam, suggesting that the ores source of Sijilmâsa slags were implemented at the same time as some ores of Jebel Aouam mining district ( 400-500 Ma) (Fig. 5c, d). Nevertheless, the Pb signature of Sijilmâsa slags is not aligned on one of the mixing lines formed by the Jebel Aouam (Fig. 5 a, b and Fig. 6a). This leads us to re- F6 ject Jebel Aouam as a source for the ore of the non-ferrous slags from Sijilmâsa.

The mineralization of Bou Madine took place during the late Neoproterozoic (Precambrian) as a result of open-space filling in relation with Pan-Africa orogeny ( 885-555 Ma; Fig. 5c, d). Bou Madine is an epithermal polymetallic deposit composed of several veins with $\mathrm{Fe}, \mathrm{Pb}, \mathrm{Zn}$, and $\mathrm{Cu}$ sulphides with significant concentrations of Ag, Au, and Sn (Bouabdellah and Levresse 2016). $\mathrm{The} \mathrm{Pb}-\mathrm{Pb}$ model ages of Bou Madine also highlight the complexity of the ores implementation (four ores paragenesis and three stages divided in several episodes). Indeed, the calculated ages of the galena ores range from $\sim 870$ to $\sim 200 \mathrm{Ma}$, that is, from Precambrian to late Liasic period as also mentioned in Abia et al. 1999. The origin of the mineralisation is thus interpreted as

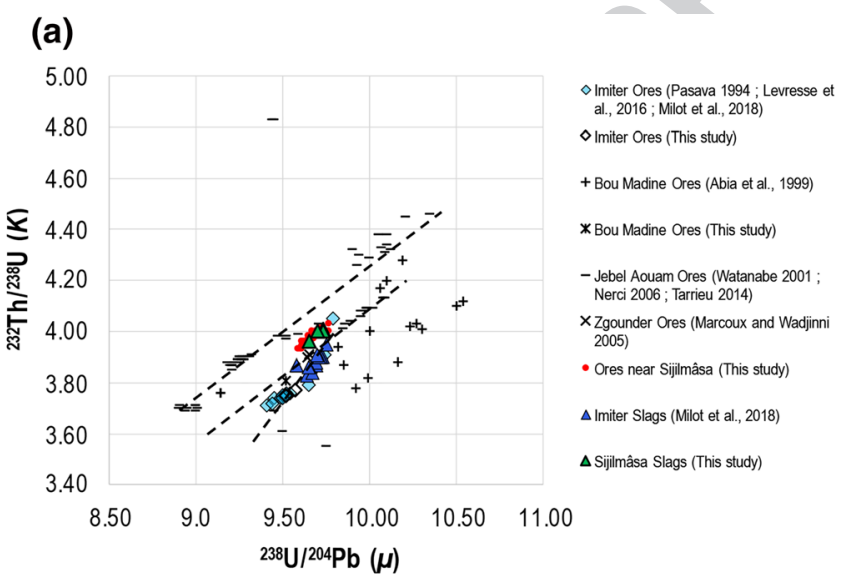

\section{(b)}

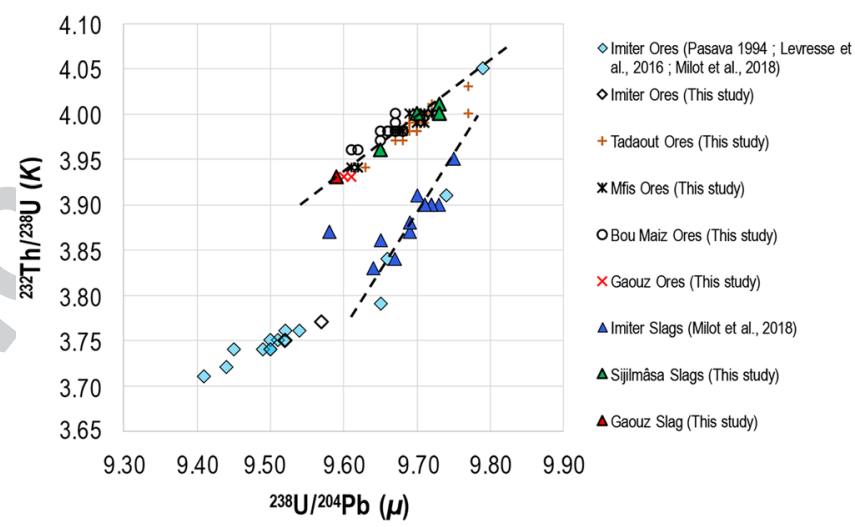

Figure 6 a) model ${ }^{238} U^{204} \mathrm{~Pb}(\mu)$ versus model ${ }^{232} \mathrm{Th}^{238} \mathrm{U}\left({ }_{\mathrm{K}}\right)$ of ores from Imiter (Levresse et al., 2016, Milot et al., 2016 and this study), Bou Madine (Abia et al. 1999 and this study), Jebel Aouam (Watanaby, 2001; Nerci 2006; Tarrieu 2014), Zgounder (Marcoux and Wadjinni 2005), ores near Sijilmâsa (this study) and of slags from Imiter (Milot et al., 2016) and Sijilmâsa (this study), b) model ${ }^{232} \mathrm{Th}^{238} \mathrm{U}_{\mathrm{K}}$ ) versus ${ }^{238} \mathrm{U}^{204} \mathrm{~Pb}(\mu)$ of ores from Imiter (Levresse et al., 2016, Milot et al., 2016 and this study), Tadout, Mfis, Bou Maix and Gaouz (this study) and of slags from Imiter (Milot et al., 2016), Sijilmâsa (this study) and Gaouz (this study). [Colour figure can be viewed at wileyonlinelibrary.com] 
reflecting a binary fluid mixing and a fluid-rock interaction with Neoproterozoic crystalline basement rocks (Bouabdellah and Levresse 2016). This is consistent with the calculated high ${ }^{232} \mathrm{Th} /{ }^{238} \mathrm{U}$ ratio $\left({ }_{K} \geq 4.00\right.$, for average $50 \%$ of ores), which characterizes a lower crustal rocks contribution (Blichert-Toft et al. 2016), such as the Neoproterozoic crystalline basement. $\mathrm{A} \mathrm{Pb}$ isotopic average effect of slags from Sijilmâsa and ores from Bou Madine could persist, as is well illustrated by the ${ }^{208} \mathrm{~Pb} /{ }^{204} \mathrm{~Pb}$ versus ${ }^{206} \mathrm{~Pb} /{ }^{204} \mathrm{~Pb}$ ratios (Fig. 5b). The Th/U ${ }_{K}$ ) ratios of Sijilmâsa and Bou Madine are quite similar although more heterogeneous for Bou Madine $(3.99 \pm 0.02$ and $3.98 \pm 0.16$, respectively; Fig. 6a), but their $\mathrm{U} / \mathrm{Pb}(\mu)$ is quite different $(9.71 \pm 0.03$ and $10.00 \pm 0.39$, respectively), and very heterogeneous for Bou Madine (Fig. 5d and 6a), and so are the ages of slags from Sijilmâsa and galena from Bou Madine ( 427 $\pm 14 \mathrm{Ma}$ and $530 \pm 175 \mathrm{Ma}$, respectively). The similarities of $\mathrm{Th} / \mathrm{U}$ ratios illustrate that the ores smelted in Sijilmâsa or at its workshop could derive from the same dynamic history of this mining province. The differences between the mean ages and U/Pb ratios (Fig. 5d and Fig. 6a) leads us to reject Bou Madine as a source for Sijilmâsa's slags.

$\mathrm{The} \mathrm{Pb}$ signature of ores from Zgounder is the result of four main geologic events beginning ca. $815 \mathrm{Ma}$, during the Pan-African orogenic cycle. The last event, at $564 \pm 15 \mathrm{Ma}$ (Precambrian, dated by $\mathrm{U} / \mathrm{Pb}$ analysis on zircons), produced the hydrothermal albitization of the Zgounder epithermal Ag-Hg deposit (Pelleter et al. 2016). This last date is similar to the calculated $\mathrm{Pb}-$ $\mathrm{Pb}$ isotope model age of $\sim 550 \mathrm{Ma}$ realised on galena by Marcoux and Wadjinny (2005). Unfortunately, a deeper discussion regarding Zgounder remains difficult because the available $\mathrm{Pb}$ signatures $(\mathrm{n}=2)$ are too few. Regardless, and on the basis of the current knowledge, the differences between $\mathrm{Pb}-\mathrm{Pb}$ model ages of Zgounder ores and slags from Sijilmâsa (Zgounder being older) would exclude a common origin (Fig. 5c,d).

The $\mathrm{Pb}$ signatures of the Imiter mine is less heterogeneous than those of Jebel Aouam and Bou Madine. Silver mineralisation of Imiter occurred in two distinct periods. Around 570-550 Ma (Pan-African age), a magmatic fluid initially produced a low-Ag precipitation. Due to geodynamic events affecting the Anti-Atlas, a second fluid input, around 300-250 Ma, reworked the older Ag deposits by lixiviation producing the implementation of the main rich-Ag ores (Essarraj et al. 2016). Calculated $\mathrm{Pb}-\mathrm{Pb}$ model ages of ores from Imiter (Pasava 1994, Levresse et al., 2016; Milot et al., 2018 and this study) are consistent (323 $\pm 56 \mathrm{Ma}$ age and a Th/U ratio of Q6 $3.78 \pm 0.08$ ) whereas the slags from Imiter have a $270 \pm 78 \mathrm{Ma}$ age and a $\mathrm{Th} / \mathrm{U}$ ratio of $3.89 \pm 0.03$. By conserving the original $\mathrm{Pb}$ signature of the fluid ore mineralisation, the ancient slags from Imiter are a good illustration of this geological history.

Linking Sijilmâsa slags with Imiter (ores and slags) would be tempting, because the $\mathrm{Pb}$ signatures are very close and a possible mixing might even have occurred, especially if we consider ${ }^{207} \mathrm{~Pb} /{ }^{204} \mathrm{~Pb}$ versus ${ }^{206} \mathrm{~Pb} /{ }^{204} \mathrm{~Pb}$, and ${ }^{208} \mathrm{~Pb} /{ }^{204} \mathrm{~Pb}$ versus ${ }^{206} \mathrm{~Pb} /{ }^{204} \mathrm{~Pb}$ ratios (Fig. 5a,b). This could lead to equate Imiter with the mine of Todgha mentioned in early medieval text as having been extant even before Sijilmâsa (Monteil 1968; Rosenberger 1970b; El Ajlaoui 1994). However, calculated $\mathrm{Pb}-\mathrm{Pb}$ model ages allow us to reject this hypothesis as galenas $(\sim 323 \pm 56 \mathrm{Ma})$ and slags $(\sim 270 \pm 78 \mathrm{Ma})$ from Imiter are too young compared to the Sijilmâsa slags ( $427 \pm 14$ Ma; Fig. 5c,d; Table S1). Furthermore, the ${ }^{232} \mathrm{Th} /{ }^{238} \mathrm{U}\left({ }_{K}\right)$ versus ${ }^{238} \mathrm{U} /{ }^{204} \mathrm{~Pb}(\mu)$ diagram highlights two different mixing lines for Imiter and Sjilmâsa (Fig. 6a,b).

\section{A city connected with its close silver mining hinterland}

Just because the slags from Sijilmâsa were found in a secondary deposit does not mean that lead-silver smelting took place at the site. On the other hand, slags, being waste products, are 
generally not traded, and we know of no other instances where slags were transported for the purpose of construction material. Rather on the contrary, and it has been well demonstrated in numerous archaeological contexts that they "stay" close to the mines (inter alia Baron et al. 2006; Domergue 2008; Hauptmann 2010; Baron et al. 2014; Fabre et al. 2016; Minvielle 2017; Bompaire and Sarah 2018). This would be enough to argue that the slags recovered from the eighth to $10^{\text {th }}$ century floor from Sijilmâsa came from mines located in the close hinterland of the city.

Indeed, a perfect $\mathrm{Pb}$ isotopic overlapping between some local ores and the Sijilmâsa slags has been observed and could point to a common origin (Fig. 5). The $\mathrm{Pb}$ ratios of silver ores from the close hinterland of Sijilmâsa and its related slags are aligned along the same mixing line (Fig. 5a,b). Indeed, according to calculated $\mathrm{Pb}-\mathrm{Pb}$ model ages, the $\mathrm{T}$ model age is similar between Sijilmâsa slags and mines near the city (Fig. 5c, d). The best silver mines sources for the Sijilmâsa slags are Bou Maiz, Tadaout, and Mfis, that is, all materials (ores and slags) exhibit the same $\mathrm{Pb}-\mathrm{Pb}$ model age $(\sim 410-420 \mathrm{Ma})$ as well as some consistent $\mathrm{Th} / \mathrm{U}$ and $\mathrm{U} / \mathrm{Pb}$ (Fig. 6a,b; Table S1). The Gaouz mining area is quite a bit younger, with an average age of $360 \mathrm{Ma}$, and has lower $\mathrm{Th} / \mathrm{U}\left(_{K}\right)$ and $\mathrm{U} / \mathrm{Pb}(\mu)$ ratios compared to the Sijilmâsa slags data (Table S1). Nevertheless, they are aligned along the same mixing line, suggesting a genetic link with the fluid source (Fig. 6b). Thus, this area has to be kept in mind, although still very few data are available, but because our prospections revealed old and interesting mining works associated with numerous slags, one being dated to the seventh c. AD, which is contemporaneous with the birth of Sijilmâsa as a city. Further geological investigations and archaeological excavations at both Sijilmâsa and Gaouz, as well as at some other still-undiscovered place that might have been used as a workshop for processing and smelting, may reveal that the mining and metallurgical activities began even before the medieval period and the foundation of the city.

\section{A lead-silver smelting ... for what use?}

Silver produced around and in Sijilmâsa in the Middle Ages may have been used to strike the silver dirhams or qirats (half dirham; Roux and Guerra 2000); it may also have been used to devalue gold currency. Indeed, elemental measurements made on Sijilmasa's gold coins highlight silver (Ag) and copper $(\mathrm{Cu})$ additions for debasement issues (Gondonneau et al. 2000; Roux and Guerra 2000; Gondonneau and Guerra 2002). For example, during the Almoravid dynasty (mid-1 $1^{\text {th }}$ to mid-12 ${ }^{\text {th }}$ c.), when Sijilmâsa was one of the major minting centre for dinars, the elemental contents of these gold coins ranged between 84 to 98 wt.\% for $\mathrm{Au}, 3$ to $14 \mathrm{wt} . \%$ for $\mathrm{Ag}$ and 0.10 to $2.10 \mathrm{wt} . \%$ for $\mathrm{Cu}$ (Roux and Guerra 2000), whereas the values obtained on modern West African gold nuggets present a fineness of gold beyond 97\% (Gondonneau et al. 2000; Guerra 2002). Natural gold/silver alloys from West Africa have not been studied at all by geology and geochemistry with regard to archaeological issues. Thus, today, the elementary (and isotopic) signatures of West African gold ores exploited by the ancients are not known. The elemental signature of a gold nugget depending both on the primary source and the distance from it doesn't mean that alluvial gold is necessarily a pure gold. By the way, analyses on gold prills embedded in crucibles from Tadmekka (Mali) yielded a 98\% fineness for gold that was traded north of the Sahara (Nixon et al. 2011; Rehren and Nixon 2014). This suggests that the gold was either refined or just melted before its trade. But above all, it suggests that the gold that came from West Africa was relatively pure, not necessarily due to mainly for geological reasons but also due to anthropogenic ones, which is, anyway, inconsistent with the elemental contents of 
the silver and copper rich-gold coins minted in Sijilmâsa. Therefore, and in view of current knowledge on the subject (which is very weak), this seems to suggest that some additions (of silver and/or copper metal) could have been operated in the gold used for coinage at Sijilmâsa city.

Another hypothesis is that Sijilmâsa may also have exported its silver.

Northwards: Fomin (1990) argue that the silver produced in Morocco may have been traded north for consumption throughout the Mediterranean basin, perhaps mostly in Europe. Additionally, North African dirhams are commonly found in the Middle East, too (Heidemann 2011), and this was perhaps a much more important in terms of global figures because most of the North African coins found in Europe travelled an eastern route originating from the central lands of the Caliphate (Kilger 2008).

Southwards: other scholars have hypothesized that silver might also have been traded to West Africa (Magnavita and Mertz-Kraus 2019), a region where it seems that silver and copper were more valued than gold. An ancient map by Giovanni da Carignano (14 ${ }^{\text {th }} \mathrm{c}$.) (Rosenberger 1970a) illustrates this silver trade toward Mauritania (Oualata), "Guinea" (i.e. Sahelian West Africa), Mali (Timbuktu), and Senegal, a region where silver jewellery has been recovered in burials (Magnavita 2017). More recently, elemental analyses conducted on gold-silver alloy artefacts found in Senegal also suggest that the silver in the objects derive from a source north of the Sahara (Magnavita and Mertz-Kraus 2019).

\section{CONCLUSION}

To conclude, isotopic analysis of slags used as a construction material between the eighth and the $10^{\text {th }}$ century in Sijilmâsa revealed that a previously unsuspected local silver mining exploitation very close to the medieval Islamic city was one of the possible places where silver metal elaboration took place during the Middle Ages.

This result brings to bear robust geological, geochemical, and archaeological confirmation that silver was produced in the vicinity of Sijilmâsa from the very foundation of the city, if not earlier. Thanks to archaeological dating coupled with geochemistry, it is the first tangible proof of regional silver production in Africa north of the Sahara in this period.

This study, we hope, will push scholars to trace the signature of this silver production in debased gold coins struck at Sijilmâsa, as well as in archaeological artefacts from West Africa and possibly other regions which were encompassed in Sijilmâsa's trading network.

\section{ACKNOWLEDGEMENTS}

We would like to thank the Centre National de la Recherche Scientifique (CNRS), the French Ministry of Foreign Affairs (MAEDI), the Federal University of Toulouse (Idex project), and the Ibn Zohr University of Taroudant in Morocco for their institutional and financial support. Special thanks to Thierry Aigouy (GET, CNRS laboratory in Toulouse) and Philippe de Parseval (UMS 3623 - Centre de Micro caractérisation Raimond Castaing, CNRS, Toulouse) for their technical assistance and advice during the SEM and EPMA analyses of slags. We are grateful to the GET laboratory (CNRS, Toulouse), in particular Manuel Henry and Jérôme Chmeleff, for clean room and MC-ICP-MS (Neptune) access. We are also grateful to the Managem group for technical support during our missions (Nabil Atlassi, Mohamed Benmoumen, Farid El Hamdaoui, Mohamed Mouhajir). Finally, we would like to thank Caroline Robion-Brunner for constructive discussions and Troy Tice for improving and editing the English. Thanks to the two experts for their insightful comments. 


\section{REFERENCES}

Abia, E. H., Nachit, H., and Baroudi, Z., 1999, Les minéralisations filoniennes à Pb-Zn et cu de la boutonnière de l'Ougnat. Relations avec les déformations et essais de calage chronologique, Chronique de la Recherche Minière, 536-537, 137-51.

Albarède, A., Desaulty, A.-M., and Blichert-Toft, Y., 2012, A geological perspective on the use of Pb isotopes in archaeometry, Archaeometry, 54, 853-67.

Austen, R., 2010, Trans-Saharan Africa in world history, Oxford University Press, New York.

Bailly-Maître, M.-C., 2002, L'argent: du minerai au pouvoir dans la France médiévale, A. et J. Picard, Paris.

Baron, S., Carignan, J., Laurent, S., and Ploquin, A., 2006, Medieval lead making on Mont-Lozère massif (CévennesFrance): Tracing ore sources by using Pb isotopes, Applied Geochemistry, 21, 241-52.

Baron, S., Le-Carlier, C., Carignan, J., and Ploquin, A., 2009, Archaeological reconstruction of medieval lead production: Implications for ancient metal provenance studies and paleopollution tracing by $\mathrm{Pb}$ isotopes, Applied Geochemistry, 24, 2093-101.

Baron, S., Tamas, C. G., and Le Carlier, C., 2014, How mineralogy and geochemistry can improve the significance of Pb isotopes in metal provenance studies? Archaeometry, 56(4), 665-80.

Blichert-Toft, J., Delile, H., Lee, C.-T., Stos-Gale, S., Billström, K., Andersen, T., Hannu, H., and Albarède, F., 2016, Large-scale tectonic cycles in Europe revealed by distinct $\mathrm{Pb}$ isotope provinces, Geochemistry, Geophysics, Geosystems, 17, 3854-64. https://doi.org/10.1002/2016GC006524.

Bompaire, M., and Sarah, G., 2018, in Mine, Métal, Monnaie, Melle: Les voies de la quantification de l'histoire monétaire du haut Moyen age. Collection "Hautes études médiévales et modernes" (ed. L. Droz), 87-110, École Pratique des Hautes Études, Paris, France ISBN 978-2-600-05736-3.

Bouabdellah, M., and Levresse, G., 2016, The Bou Madine polymetallic ore deposit, eastern anti-atlas, Morocco: Evolution from massive Fe-as-Sn to epithermal au-ag- $\mathrm{Zn} \pm \mathrm{cu}$ mineralisation in a Neoproterozoic resurgent caldera environment, in Mineral deposits of North Africa, mineral resource reviews (eds. M. Bouabdellah and J. F. Slack), 133-42, Springer International Publishing, Switzerland.

Boussalh, M., Jlok, M., Guillaud, H., and Moriset, S., 2005, Manuel de conservation du patrimoine architectural en terre des vallées présahariennes du Maroc. CERKAS, Centre du patrimoine mondial de l'UNESCO, CRATerre, 79 p.

Cipolla, C. M., 1956, Money, prices, and civilization in the Mediterranean world, Princeton University Press, Princeton, New Jersey.

Colin, G. S., 1936a, Les mines marocaines et les marocains, Bulletin Economique du Maroc, 3(13), 194-200.

Colin, G. S., 1936b, Monnaies de la période Idrisside trouvées à Volubilis, Hespéris, XXII, 113-25.

Colin, G. S., 1954, L'exploitation de la mine d'argent de Zgounder au XIII 's, Hespéris, XLI, 228-9.

Cressier, P., 2004, Du Sud au Nord du Sahara: la question de Tâmdult (Maroc), in Du Nord au Sud du Sahara. Cinquante ans d'archéologie française en Afrique de l'Ouest et au Maghreb. Bilan et perspectives (eds. A. Bazzana and H. Bocoum), 275-85, Sépia, Paris.

Darles, C., Malet, E., Mathieu, C., Nicol, A., Erbati, E., and Fauvelle, F.-X., 2016, La Porte Bab al-Mansouria, au Nord de Rissani (Maroc) : Description, comparaisons et proposition de séquence historique d'un vestige architectural, Bulletin d'Archéologie Marocaine, 23, 243-63.

Domergue, C., 2008, Les mines antiques. La production des métaux aux époques grecque et romaine, A. et J. Picard, Paris.

El Ajlaoui, M., 1994, La mine d'argent d'Imidar et la question de Todgha (VIII-Xe siècle) : Vers Une hypothèse, Hespéris Tamuda, 32, 11-33.

Essarraj, S., Boiron, M.-C., Cathelineau, M., Tarantola, A., Leisen, M., Boulvais, P., and Maacha, L., 2016, Basinal brines at the origin of the Imiter ag-hg deposit (anti-atlas, Morocco): Evidence from LA-ICP-MS data on fluid inclusions, halogen signatures, and stable isotopes (H, C, O), Economic Geology, 111, 1753-81.

Fabre, J., Domergue, C., and Dabosi, F., 2016, Le fer romain de la Montagne noire. Martys 2: Les débuts. 25 années de recherches pluridisciplinaires (1988-2013), Supplément à Revue Archéologique de Narbonnaise, Presses Universitaires de la Méditerranée, Montpellier.

Fauvelle, F.-X., 2018, The Golden rhinoceros: Histories of the African middle ages, Princeton University Press, Princeton, New Jersey.

Fauvelle, F.-X., Erbati, L., and Mensan, R., 2014, Sijilmasâ: Cite idéale, site insaisissable ? Ou comment Une ville échappe à ses fouilleurs, Les Etudes et Essais du Centre Jacques Berque, 20, 4-17.

Fauvelle, F.-X., Erbati, E., Mensan, R., and Daussy, A., 2018, The periphery walls of Sijilmâsa, a medieval Islamic city in Morocco: Contribution to the identification of typological and functional variability of the pisé technique, in Earthen architecture in Muslim cultures: Historical and anthropological perspectives (ed. S. Pradines), 37-54, Brill, Leide. 
Frizon de Lamotte, D., Crespo-Blanc, A., Saint-B'ezar, B., Comas, M., Fernadez, M., Zeyen, H., Ayarza, H., RobertCharrue, C., Chalouan, A., Zizi, M., Teixell, A., Arboleya, M. L., Alvarez-Lobato, F., Julivert, M., and Michard, A., 2004, TRANSMED-transect I [Betics, Alboran Sea, Rif, Moroccan Meseta, high atlas, Jbel Saghro, Tindouf basin], in The TRANSMED atlas - The Mediterranean region from crust to mantle (eds. W. Cavazza, F. Roure, W. Spakman, G. M. Stampfli, and P. A. Ziegler), S,pringer, Berlin.

Fomin, A., 1990, Silver of the Maghrib and gold from Ghana at the end of the VIII-IXth centuries a. D, in Sigtuna papers. Proceedings of the Sigtuna Symposium on Viking Age Coinage (1989), 69-75, Regesta Imperii, Stockholm.

Garenne-Marot, L., and Mille, B., 2007, Copper-based metal in the inland Niger delta: Metal and technology at the time of Q8 the empire of Mali, in Metals and mines: Studies in archaeometallurgy (eds. S. La Niece, D. Hook, and P. Craddock), 159-69, Archetype Publications Ltd. in association with the British Museum, London.

Garenne-Marot, L., Robion, C., and Mille, B., 2003, Cuivre, alliages de cuivre et histoire de l'empire du Mali. A propos de trois figurines animales d'un tumulus du delta intérieur du Niger (Mali), Technè, 18, 74-85.

Gasquet, D., Levresse, G., Cheilletz, A., Azizi-Samir, M. R., and Mouttaqi, A., 2005, Contribution to a geodynamic reconstruction of the anti-atlas (Morocco) during pan-African times with the emphasis on inversion tectonics and metallogenic activity at the Precambrian-Cambrian transition, Precambrian Research, 140, 157-82.

Gassmann, G., and Schäfer, A., 2018, Doubting radiocarbon dating from in-slag charcoal: Five thousand years of iron production at Wetzlar-Dalheim? Archeologické Rozhledy, LXX, 309-27.

Gondonneau, A., and Guerra, M. F., 2002, The circulation of precious metals in the Arab empire: The case of the near and the middle east, Archaeometry, 44(4), 573-99.

Gondonneau, A., Roux, C., Guerra, M. F., and Morrisson, C., 2000, La frappe de la monnaie d'or à l'époque de l'expansion musulmane et les mines de l'ouest de l'Afrique: l'apport analytique, in Proceedings - Actes XII. Internationaler Numismatischer Kongress Akten II-Berlin 1997 (eds. B. Kluge and B. Weisser), 1264-74, , Berlin.

Gouchet, C. L., Teilhet, J. H., Wilson, K. R., and Chow, T. J., 1976, Lead isotope studies of metal sources for ancient Nigerian 'bronzes', Nature, 262, 130-1.

Guerra, M. F., 2002, Ancient gold and modern techniques: Identification of gold supplies from Croesus to Mohamed using accelerators and ICP-MS, in Proceedings Art 2002:7th International Conference on Non-destructive Testing and Microanalysis for the Diagnostics and Conservation of the Cultural and Environmental Heritage, University of Antwerp.

Hauptmann, A., 2010, in The Archaeometallurgy of copper. Evidence from Faynan, Jordan (eds. B. Herrmann and G. A. Wagner), Natural Science in Archaeology, Publication of the Deutsches Bergau-Museum Bochum, Springer-Verlag, Berlin Heidelberg https://doi.org/10.1007/978-3-540-72238-0.

Heidemann, S., 2011, The circulation of north African dirhams in northern Mesopotamia - The dirham hoard of tall alBī_x02BF;a/al-Raqqa (t.p.q. 186/802), Revue Numismatique, 167, 451-70.

Hourri, F., Dekayir, A., and Makdoun, M., 2017, Mineralogy and chemical compositions of ancient slags from Volubilis archaeological site and Awam ancient mine (Morocco), STAR: Science \& Technology of Archaeological Research, 3(2), 238-44. https://doi.org/10,1080/20548923.2018.1433269.

Keesmann, I., 2001, Untersuchunger zur mettalurgie im archaischen und Punischen Karthago, Mediterranean Archaeology, 14, 95-108 https://www.jstor.org/stable/24667994.

Kilger, C., 2008, Kaupang from Afar: Aspects of the interpretation of dirham finds in northern and Eastern Europe between the late 8th and early 10th centuries, in Means of exchange (ed. D. Skre), 199-252, Aarhus University Press, Aarhus.

Levresse, G. 2001, Contribution à l'établissement d'un modèle génétique des gisements d'Imiter (ag - hg), Bou Madine $(\mathrm{Pb}-\mathrm{Zn}-\mathrm{cu}-\mathrm{ag}-\mathrm{au})$ et Bou Azzer (co - Ni -as - au - ag) dans l'Anti atlas marocain. PhD thesis, University of Lorraine, Nancy, France.

Levtzion, N., and Hopkins, J. F., 2000, Corpus of early Arabic sources for west African history, Markus Wiener, Princeton (NJ).

Magnavita, S., and Mertz-Kraus, R., 2019, XRF and LA-ICP-MS studies of gold and silver artefacts from a 12-13th century CE tumulus in Senegal: Implications for the medieval African gold trade, Journal of Archaeological Science, 23, 416-25.

Magnavita, S., 2017, First geophysical exploration in the tumuli zone of Central Senegal: A multidimensional approach, Azania: Archaeological Research in Africa, 52(1), 100-22.

Marcoux, E., and Wadjinny, A., 2005, Le gisement ag-hg de Zgounder (Jebel Siroua, anti-atlas, Maroc): Un épithermal néoprotérozoïque de type Imiter, Comptes Rendus Geoscience, 337, 1439-46.

Messier, R. A., and Miller, J. A., 2015, The last civilized place: Sijilmâsa and its Saharan destiny, University of Texas Press, Austin, Texas. 
Messier, R. A., 1997, Sijilmassa. Five seasons of archaeological inquiry by a joint Moroccan-American Mission, Archéologie Islamique, 7, 61-92.

Messier, R. A., 1973, The Almoravids. West African gold and the gold currency of the Mediterranean basin, Journal of the Economic and History of the Orient, XVII(Part I), 31-42.

Michard, A., Saddiqui, O., Chalouan, A., and Frizon de Lamotte, D. (eds.), 2008, Continental evolution: The geology of Morocco: Structure, stratigraphy, and tectonics of the Africa-Atlantic-Mediterranean triple junction, 426, Lecture Notes in Earth Sciences, Vol. 116, Springer-Verlag, Berlin Heidelberg 10.1007/978-3-540-77076-3.

Minvielle, N., 2017, L'âge de l'argent. Mines société et pouvoirs en Languedoc médiéval. Ph.D. thesis, University of AixMarseille, France.

Monod, Th., 1969, Le "Ma'den Ijafen”, Une épave caravanière dans le Majabat Al-Koubra, in Actes du ler Colloque International d'Archéologie africaine, Fort-Lamy, décembre 1966, 11-16, 286-320, Etudes et Documents Tchadiens, Mémoires 1.

Monteil, V., 1968, Al-Bakrî (Cordoue 1068). Routier de l'Afrique blanche et noire du Nord-Ouest, Bulletin de l'IFAN, série $B, \mathbf{X X X}(1), 39-116$.

Muqaddasi, 1950, Description de l'occident musulman au $I V^{e}-X^{e}$ siècle, Alger. Trad. Ch, Pellat.

Nerci, K., 2006, Les minéralisations aurifères du district polymétallique de Tighza (Maroc central): Un exemple de mise en place périgranitique tardi-hercynienne. Ph. D. Thesis, University of Orléans, France. $<$ tel-00177417>.

Niemeyer, H., 2001, Archaeological evidence of early iron technology at Carthage and other Phoenician settlements, Mediterranean Archaeology, 14, 83-93 http://www.jstor.org/stable/24667993

Nixon, S., Rehren, T., and Guerra, M. F., 2011, New light on the early Islamic west African gold trade: Coin moulds from Tadmekka, Mali, Antiquity, 85, 1353-68.

Pasava, J., 1994, Geochemistry and the role of anoxic sediments in the origin of the Imiter silver deposit in Morocco, Vestnik Ceskeho geologickeho ustavu, 69(1), 1-2.

Pelleter, E., Cheilletz, A., Gasquet, D., Mouttaqi, A., Annich, M., Camus, Q., Deloule, E., Ouazzani, L., Bounajma, H., and Ouchtouban, L., 2016, U/Pb ages of magmatism in the Zgounder epithermal ag-hg deposit, Sirwa window, antiAtals, Morocco, in Mineral deposits of North Africa, mineral resource reviews (eds. M. Bouabdellah and J. F. Slack), 143-65, Springer International Publishing, Switzerland.

Rehren, T., and Nixon, S., 2014, Refining gold with glass - An early Islamic technology at Tadmekka, Mali, Journal of Archaeological Science, 49, 33-41.

Rosenberger, B., 1964, Autour d'une grande mine d'argent du moyen âge marocain: le Jebel Aouam, Hespéris-Tamuda Rabat, 5, 15-78.

Rosenberger, B., 1970a, Les anciennes exploitations minières et les anciens centres métallurgiques du Maroc: Essai de carte historique ( $2^{\text {nd }}$ partie), Revue de Géographie du Maroc Faculté des Lettres Rabat, 18, 59-101.

Rosenberger, B., 1970b, Les vieilles exploitations minières et les anciens centres métallurgiques du Maroc: Essai de carte historique (1 ${ }^{\mathrm{èr}}$ partie), Revue de Géographie du Maroc Faculté des Lettres Rabat, 18, 71-107.

Rosenberger, B., 1970c, Tamdult, cite minière et caravanière présaharienne $\mathrm{IX}^{\text {ème }}-\mathrm{XVI}^{\mathrm{ème}}$ siècles, Hespéris-Tamuda Rabat, 11, 103-39.

Rossi, M., Tarrieu, L., Cheilletz, A., Gasquet, D., Deloule, E., Paquette, J.-L., Bounajma, H., Mantoy, T., Ouazzani, L., and Ouchtouban, L., 2016, The polymetallic (W-au and Pb-Zn-ag) Tighza District (Central Morocco): Ages of magmatic and hydrothermal events, in Mineral deposits of North Africa, mineral resource reviews (eds. M. Bouabdellah and J. F. Slack), 107-32, Springer International Publishing, Switzerland.

Roux, C., and Guerra, M. F., 2000, La monnaie Almoravide: de l'Afrique à l'Espagne, Revue d'Archéométrie, $24,39-52$.

Saadi, M., 1971, Der alte Bergbau Marokkos, in Sonderdruck aus Geologie, Jahrgang 20, Heft 4/5, 570-81, AkademieVerlag, Berlin.

Soubira, T., Fauvelle, F.-X., Erbati, E., and Mensan, R., 2015, Sijilmâsa (Morocco): The urbanism of a medieval Islamic site as seen through its hydraulic system (8th-13th centuries AD), Nyame Akuma, 84, 3-12.

Stacey, J. S., and Kramers, J. D., 1975, Approximation of terrestrial lead isotope evolution by a two-stage model, Earth and Planetary Science Letters, 26(2), 207-21.

Tarrieu, L., 2014, Nouvelles données minéralogiques, géochimiques et géochronologiques Sur le gisement polymétallique de Tighza (Maroc-central) : Contribution à la métallogénie des gisements de métaux de base filoniens en contexte post-collisionnel. Ph.D. thesis, University of Grenoble, France. <tel-01126839>.

Thirlwall, M. F., 2002, Multicollector ICP-MS analysis of the $\mathrm{Pb}$ isotopes using a ${ }^{207} \mathrm{~Pb}^{204} \mathrm{~Pb}$ double spiking demonstrates up to $400 \mathrm{ppm} / \mathrm{amu}$ systematic errors in Tl-normalization, Chemical Geology, 184, 255-79.

Tuduri, J., 2005, Processus de formation et relations spatio-temporelles des minéralisations à or et argent en contexte volcanique Précambrien (Jbel Saghro, anti-atlas, Maroc) : Implications Sur les relations déformation-magmatismevolcanisme-hydrothermalisme. Ph.D. thesis, University of Orléans, France. 
Tylecote, R. F., 1980, Metallurgy in Punic and Roman Carthage, in Mines et fonderies antiques de la Gaule, Table ronde du CNRS Toulouse-Le Mirail, Toulouse (1982).

Watanabe, Y., 2002, ${ }^{40} \mathrm{Ar}{ }^{39} \mathrm{Ar}$ Geochronologic constraints on the timing of massive sulfide and vein-type Pb-Zn mineralization in the Western Meseta of Morocco, Economic Geology, 97, 145-75.

Zigari, B., 1963, Description et inventaire des filons minéralisés de Bou Maiz au Sud de Rissani, 758, S.E.G.M. (service d'Etudes des Gîtes et Minéraux).

\section{SUPPORTING INFORMATION}

Additional supporting information may be found online in the Supporting Information section at the end of the article.

Table $\mathrm{S} 1 \mathrm{~Pb}$ isotopic signatures and calculated $\mathrm{T}(\mathrm{Ma}),{ }^{232} \mathrm{Th} /{ }^{238} \mathrm{U}\left({ }_{K}\right)$ and ${ }^{238} \mathrm{U} /{ }^{204} \mathrm{~Pb}(\mu)$ (Albarède et al. ) of ores from the hinterland of Sijilmâsa and the non-ferrous slags recovered during the excavation of the city. 